\title{
Armed only with knowledge
}

\section{Physicist Patrick Blackett made a stand against atomic weapons.}

\author{
Blackett: Physics, War, and \\ Politics in the Twentieth Century \\ by Mary Jo Nye \\ Harvard University Press: 2004. 272 pp. \\ $\$ 39.95, £ 25.95$, €36.90 \\ Jon Agar
}

A prominent scientist visits the United States at election time and records a "conservative turn in American politics and an eagerness to talk about preventive war". Rather than trim his sails to meet the prevailing wind, he redoubles his determination to speak the truth about weapons of mass destruction. He subsequently writes a book that is criticized from all sides, and is labelled a defeatist, even a traitor of sorts. It will take many years for the historical consensus to catch up.

The scientist was Patrick Blackett, and the book was his 1948 work The Military and Political Consequences of Atomic Energy. "The experiences of Blackett in his public campaign against nuclear weapons," writes his biographer Mary Jo Nye, "illustrate the risks to a physicist of writing about a subject other than physics, as well as the circumstances that might compel one to do so."

The traditional function of a biography was to provide lessons, drawn from a past life, by which contemporary readers should aspire to live their lives. The emphasis was on character. Nye's biography of Blackett, although modern in its approach to the history of science, is nevertheless oddly traditional. In seeking to provide an account of how the physicist could navigate so successfully between theory and experimental craft, and between the laboratory and the corridors of power, she focuses on his virtuous characteristics, including "versatility of imagination", "tough skepticism" and being "fiercely independent".

The children of a century ago were blessed: the most radical technologies of their day could be taken apart, built, rebuilt and understood with their own hands. "I spent every hour out of school making wireless sets and model aeroplanes," Blackett recalled. The knowledge gained from this tinkering got him into the Royal Naval College at Osborne House on the Isle of Wight: the admissions board judged him the "right sort of boy". The young naval cadet built his own cameras. On active duty he witnessed the Battle of the Falklands in 1914. In quieter moments he continued with photography.

Blackett's manipulative skill flourished when, after demobilization, he joined Ernest Rutherford's Cavendish Laboratory at the University of Cambridge, where the most

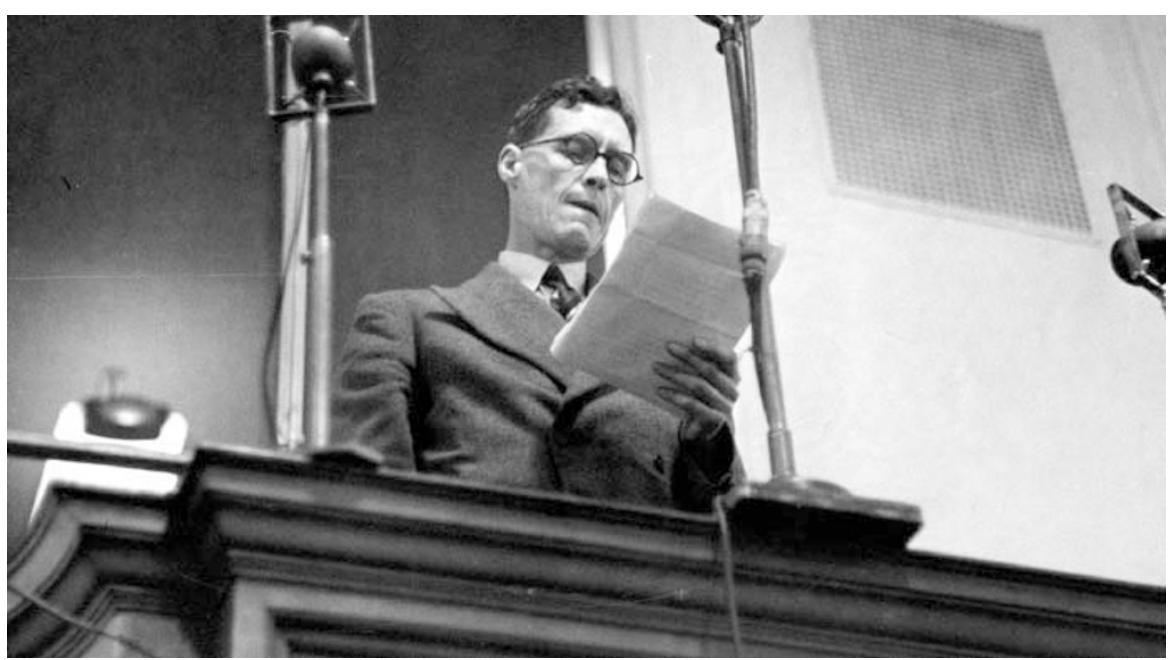

Speaking out: Patrick Blackett was labelled a traitor for arguing against UK work on an atomic bomb.

remarkable series of discoveries in twentiethcentury physics were crafted.

Blackett constructed automatic cloud chambers in which the passage of a particle triggered a photograph of the event. Working with Giuseppe Occhialini, he turned the device towards the mysterious cosmic rays. "What not everyone had the chance to see," Occhialini later noted, "was the passionate intensity with which he worked. I can still see him, that Saturday morning when we first ran the chamber, bursting out of the darkroom with four dripping photographic plates held high, and shouting for all the Cavendish to hear, 'One on each Beppe, one on each!'”

But, as Nye writes, intensity was balanced by tough skepticism. In 1932, faced with a small number of extraordinary tracks, Blackett identified them with one of his colleague Paul Dirac's most exotic predictions, positively charged electrons. Yet he refused to rush into print — one reason why the 1936 Nobel prize went to his rival at the California Institute of Technology, Carl Anderson.

Francis Everitt, one of Blackett's students, claimed that two remarks encapsulated Blackett's outlook: "Make sure you gather plenty of data," and "Treat your research like a military campaign.” Others, too, clearly learned the lesson. When Blackett restarted his cosmic-ray programme at Manchester University after the Second World War, George Rochester and Clifford Butler soon announced their discovery of kaons, or Kmesons, in Nature: "There are two photographs containing forked tracks of a very striking character. These photographs have been selected from five thousand photographs taken in an effective operation time of 1,500 hours". Plenty of data there.
Nor is it surprising that the ex-naval cadet treated research like a military campaign. However, during the war Blackett achieved something with far greater ramifications: he treated military campaigns as research, inventing a new science, operational research, as a result. In 1933, Blackett had moved to Birkbeck College, London. The problems he faced of limited financial support for his impoverished physics laboratory were easily outweighed by the advantages of his "fierce independence", free from Rutherford and free to choose his own research direction.

London also meant induction into the political establishment. The socialist Blackett was recruited by Henry Tizard to advise on air defence, in particular the development of radar. After war broke out, he assembled interdisciplinary teams of scientists to work closely with military personnel. The stuff of the operations rooms - flight books, radiolocation data and ship positions - became the data of operational research. This was a new science, not because its approach was new, but because it marked a close and supplementary relationship between scientific expertise and military power.

When Blackett wrote in November 1941 to his friend Michael Polanyi, an émigré chemist of opposing political views, Blackett asked: "You speak as if it is always a duty to publish the 'truth'. If I had published the truth of what I have known of parts of our war effort, I would certainly be locked up. Should I have done so?". What was the truth in question? Blackett had sided with Tizard in opposing Frederick Lindemann's advocacy of bombing civilian populations, and he had done so on the basis of operational research. By then, other means of mass destruction were being debated. 
From 1940, Blackett sat on the MAUD Committee, assessing the likelihood that research on nuclear chain reactions would lead to a practical atomic weapon within the timespan of the war. At first he was the lone British voice calling for the weapon to be developed only by the United States. After the war, and particularly after the 1946 McMahon Act broke with any pretence of joint UK-US responsibility for the bomb, Blackett argued vehemently against a British bomb project. He tried private routes of influence, but was rebuffed by the prime minister, Clement Attlee. So he went public, writing The Military and Political Consequences of Atomic Energy.

"Neither communist nor pacifist, Blackett had no argument with war," writes Nye, so why did Blackett take such "an outspoken and unpopular political position on matters of nuclear policy immediately following the Second World War?" Because his naval and operational-research experience taught him that policy decisions driven by inadequate knowledge were likely to be wrong. And because he was appalled by war-games theorizing, which he viewed as inhuman. Jon Agar is in the Department of History and Philosophy of Science, University of Cambridge, Cambridge CB2 3RH, UK.

\section{Living with viruses}

\section{Viral Fitness: The Next SARS and West Nile in the Making \\ by Jaap Goudsmit \\ Oxford University Press: 2004. 202 pp.}

$£ 18.50, \$ 29.95$

\section{Steven Wolinsky}

Breathing can kill you. So can eating and drinking. We live in a world where pathogenic microorganisms in air, food and water pose an omnipresent threat to human health and agriculture. Yet we continue to expand our global presence, engage in highrisk sexual behaviour, and produce more crops and domesticated animals bred for traits that restrict their diversity. As a result, we are exposing ourselves to dangerous viral pathogens that can cause epidemics on a scale seen only in apocalyptic novels. Viruses will inevitably help decimate our natural world and humans as well. So claims Jaap Goudsmit in his engaging new book, Viral Fitness.

Goudsmit, a professor of communicable diseases at the University of Amsterdam in the Netherlands, chooses several diseases of plants, animals and humans as case studies in the epidemiology and evolutionary biology of emerging viral pathogens. He highlights important ecological factors in the emergence of viruses, such as the role of waterfowl in the rise of the $\mathrm{H} 5 \mathrm{~N} 1$ influenza virus,

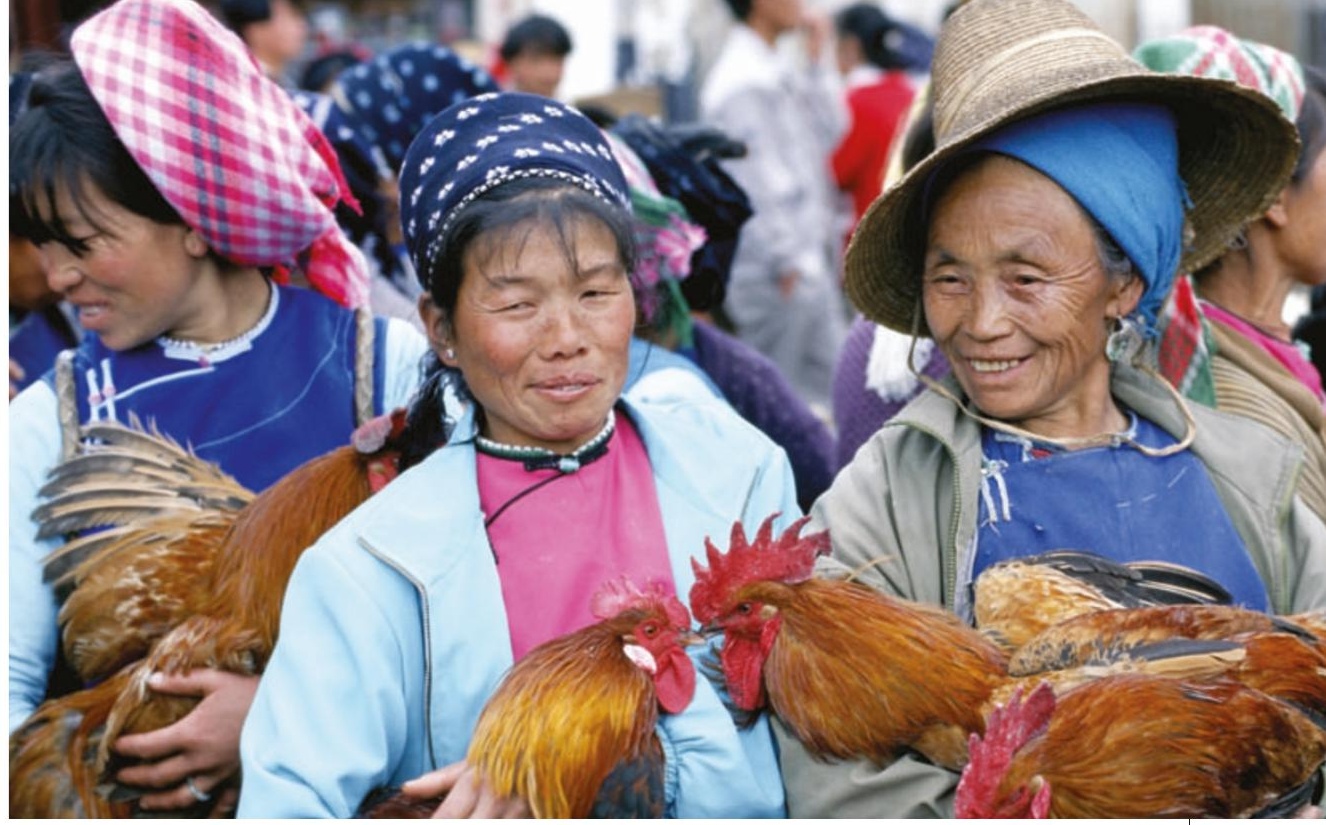

Paying the price: the H5N1 influenza virus that caused avian flu was spread in Chinese markets.

which led to an outbreak of avian flu in Asia; the part the bushmeat trade played in the appearance of HIV in Africa; and the role of the consumption of palm civet in the spread of the coronavirus that causes severe acute respiratory syndrome (SARS).

To become dangerous to humans, such viruses must cross the species barrier, which requires both genetic factors and incursions into new ecological niches. Antibodies against the SARS coronavirus from the Himalayan palm civet, the putative species of origin, have been found in other animals sold at local Chinese markets, implying that there are constraints to adaptation across species. Goudsmit points out that few transmission events are sustained. Monkeypox virus and the $\mathrm{O}$ and $\mathrm{N}$ groups of HIV type 1 , for example, infected human hosts with limited subsequent transmission. This suggests that dead-end transfers of viruses with imperfect adaptation to the new host species may be common, and that transmission of a pathogen that spreads to epidemic proportions may be the exception rather than the rule.

Goudsmit deftly reconstructs epidemiological history and relates how climatic changes, population movements and trade have converged to help viruses emerge and spread. Many of these anecdotes are well known, but others are not. Goudsmit artfully unravels the threads that tie together the evolutionary selection processes working in the new host species. Because viruses have large population sizes, high mutation rates and short generation times, they are capable of rapid genetic evolution. Once inside the host, virus populations are shaped by forces of evolutionary change that include mutation, genetic recombination and natural selection. This complex interplay between the virus and its host - both in a single individual and in the population - can result in a variety of outcomes. For example, the introduction into Australia of a myxomavirus to reduce the rabbit population was highly successful, through an accidental experiment of nature. At first, rabbit numbers were drastically reduced. Over time, however, a milder strain emerged that was more effective at infecting rabbits. Through selection, the virus evolved to a less virulent form, illustrating the important difference between evolutionary fitness and virulence.

Despite the fascinating examples he cites, Goudsmit fails to address some critical topics, such as the contribution of host and virus genetic heterogeneity and coevolution, and the role of frequency-dependent selection in evolutionary change. Several of his suggestions are untenable, such as the idea that a new virus can emerge after an asexual ménage à trois among unrelated viruses in a single cell; not every virus can infect every cell. Viruses have anthropomorphic desires and a teleological end in view, according to Goudsmit. Other topics, such as the role of viruses in making possible our evolutionary development, and the use of phage therapy for clinical and agricultural applications, add another dimension to the host-pathogen relationship.

To bolster the claim that viruses are a threat to us now "more than ever before", Goudsmit considers epidemiological and evolutionary dynamics alongside the course of human events, but neglects to mention many public-health successes. Health officials are scrambling, so far with relative success, to contain the SARS coronavirus and prevent the spread of the influenza H5N1 and H7N7 viruses from waterfowl to humans. No mention is made of the important change to seasonal outbreaks of influenza achieved by simply moving pigs away from ducks on Chinese farms.

How can we avoid the dangers that nature presents? Wash your hands. Cover your mouth when you sneeze. Refrain from transplanting animal organs, Goudsmit would also add, and don't eat monkeys. Vaccines help to halt viruses that cause epidemics such as measles, which cause short infections 